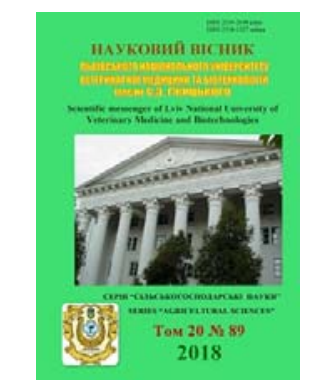

Науковий вісник Дьвівського національного університету ветеринарної медицини та біотехнологій імені С.З. Гжицького

UDC 636.082.02

\title{
Extraterritorial-constitutional features of Black-and-Spotted Dairy cows of different affinity and production types
}

\author{
O.M. Golub, S.G. Shalovylo, A.O. Bojko, R.S. Oseredchuk \\ Stepan Gzhytskyi National University of Veterinary Medicine and Biotechnologies Lviv, Ukraine
}

Article info

Received 31.08.2018 Received in revised form 02.10 .2018

Accepted 03.10.2018

Stepan Gzhytskyi National Universityof Veterinary Medicine and Biotechnologies Lviv, Pekarska Str., 50, Lviv, 79010, Ukraine. Tel.: +38-097-995-18-60 E-mail:okgolub@gmail.com
Golub, O.M., Shalovylo, S.G., Bojko, A.O., \& Oseredchuk, R.S. (2018). Extraterritorialconstitutional features of Black-and-Spotted Dairy cows of different affinity and production types. Scientific Messenger of Lviv National University of Veterinary Medicine and Biotechnologies, 20(89), 41-46. doi: 10.32718/nvlvet8907

The evaluation of animals by exteriors and constitutions is an important component in an integrated selection system. Exterior of farm animals is an external manifestation of the constitution and fully characterizes their tribal, productive and adaptive capabilities. The exteriors also assess the degree of animal typical for the line, family, because the type of body structure, along with the indicators of milk productivity is the main selection criterion for the improvement of any breed. The research was carried out on a herd of cows of Ukrainian Black-and-Spotted Dairy breed in the amount of 320 heads in the LTD "Pershe Travnya" Drohobych district Lviv region. The definition of productive types was carried out in accordance with the recommendations from the evaluation of the type of body tissue of dairy cattle of Derzhagroprom of Ukraine (1991). In the result of the evaluation, two groups of animals were identified: milk and milk and meat types. At the same time, in each production type, two groups of cows were established by the method of genealogical analysis: I- up to 75\% and II-over 75\% of the inheritance of Holstein breed. As a result of the conducted research, it was established that the cows of the Ukrainian Black-and-Spotted Dairy breed are characterized by strong body structure and good muscle development. The assessment of exterior - constitutional parameters of experimental animals revealed, that from 320 cows to dairy type belong 170 heads, or $55.6 \%$, and to a milk-meat type - 142 heads, or $44.4 \%$. It was installed that the cows of Ukrainian Black-and-Spotted Dairy breed of various types of production, despite the same conditions of keeping, are distinguished by the following measurements: height at the withers - $132.9-136.2 \mathrm{~cm}$, height in the back $-135.8-138.9 \mathrm{~cm}$, height in the sacrum $-137.7-140.7 \mathrm{~cm}$, depth of chest $-72.9-75.9 \mathrm{~cm}$, breast width $43.4-45.9 \mathrm{~cm}$, breast circumference $-193.3-196.4 \mathrm{~cm}$, curvature of the body $-160.7-165.3 \mathrm{~cm}$, spit curve length of the back $-53.6-55.1 \mathrm{~cm}$, girth heel $-19.7-20.5 \mathrm{~cm}$. The indicated measurements in the section of lactation in high-clover cows compared to animals with a proportion of heredity of holstein to $75 \%$ are generally higher in both types of production. This indicates that with the increase in genotypes the share of heredity and among the animals of the milk-meat type are formed externality signs with a bias in the milk type.

Key words: Ukrainian Black-and-Spotted Dairy breed, Holstein bree, exterior evaluation, body structure, dairy type, milk-meat type, genealogical analysis.

\section{Екстер'єрно-конституційні особливості корів української чорно-рябої молочної породи різної кровності та виробничих типів}

\author{
О.М. Голуб, С.Г. Шаловило, А.О. Бойко, Р.С. Осередчук
}

Львівський національний університет ветеринарної медицини та біотехнологій ім. С.З. Гљицького, м. Львів, Україна

Оиінка тварин за екстер'єром та конституиією є важливою складовою в комплексній системі селекиї. Екстер'єр сільськогосподарських тварин є зовнішнім проявом конституції і повною мірою характеризує їх племінні, продуктивні й адаптаційні можливості. За екстер'єром також очінюють ступінь типовості тварин для лінії, родини, оскільки тип будови тіла поряд з показниками молочної продуктивності є головною селекційною ознакою при удосконаленні будь-якої молочної породи. Дослідження проводили на стаді корів украӥнської чорно-рябої молочної породи в кількості 320 голів у ТзОВ “Перше Травня” Дрогобицького району Львівської області. Визначення виробничих типів проводили згідно з рекомендачіями з оцінки типу будови тіла молочної худоби 
Держагропрому Украӥни (1991). У результаті проведеної оцінки було виділено дві групи тварин: молочного типу та молочном'ясного. Одночасно в кожному виробничому типі методом генеалогічного аналізу були встановлені дві групи корів: I - до $75 \%$ і II - понад 75\% частки спадковості голштинської породи. У результаті проведених досліджень встановлено, цзо корови української чорно-рябої молочної породи характеризуються міџною будовою тіла та добрим розвитком мускулатури. Оиінка екстер'єрноконституційних параметрів піддослідних тварин виявила, ше із 320 корів до молочного типу належали 178 гол., або 55,6\%, а до молочно-м ясного типу - 142 гол., або 44,4\%. Встановлено, ичо корови української чорно-рябої молочної породи різних виробничих типів, незважаючи на однакові умови утримання, відрізняються між собою екстер'єрно-конституційними особливостями. Повновікові корови характеризуються такими промірами: висота в холиі-132,9-136,2 см, висота в спині - 135,8-138,9 см, висота в крижах - 137,7-140,7 см, глибина грудей - 72,9-75,9 см, ширина грудей - 43,4-45,9 см, обхват грудей - 193,3-196,4 см, коса довжина тулуба - 160,7-165,3 см, коса довжина заду - 53,6-55,1 см, обхват n'ястка - 19,7-20,5 см. Вказані проміри в розрізі лактацій у висококровних корів порівняно з тваринами з часткою спадковості голитинів до 75\% переважно вищі в обох виробничих типах. Це свідчить, щуо з наростанням в генотипах частки спадковості голштинів і серед тварин молочно-м'ясного типу формуються екстер'єрні ознаки характерні для молочного типу.

Ключові слова: корови, украӥнська чорно-ряба молочна порода, голштинська порода, екстер'єрна очінка, будова тіла, молочний тип, молочно-м'ясний тип, генеалогічний аналіз.

\section{Вступ}

У селекційній практиці молочного скотарства значна увага приділяється оцінці і добору худоби за зовнішніми ознаками і пропорціями будови тіла (Kuziv and Fedorovych, 2016; Bodnaruk et al., 2017). Багато дослідників виявили зв'язок між екстер'єрноконституційними характеристиками тварин i їх продуктивністю та тривалістю господарського використання, тобто у тварин встановлено певний зв'язок між екстер'єром і будовою тіла та функціональним станом організму як цілісної біологічної системи (Siratskyi et al., 2001; Khmelnychyi, 2003; Pelekhatyi and Omelkovych, 2008; Cherniak and Honcharuk, 2011; Dundun, 2016; Poslavska et al., 2016). Оцінка екстер'єру і ії важливість обумовлює використання показників будови тіла при обчисленні індексів комплексної оцінки корів і бугаїв за якістю нащадків і $є$ загальноприйнятою у країнах з розвиненим молочним скотарством (Fedak, 2001; Koval, 2003; Ruban, 2003; Shcherbatyi et al., 2016; Shcherbatyj et al., 2017).

\section{Матеріал і методи досліджень}

Об'єктом досліджень послужило стадо корів української чорно-рябої молочної породи в кількості 320 голів у ТзОВ "Перше Травня" Дрогобицького району Львівської області.

\section{Таблиця 1}

Розподіл корів української чорно-рябої молочної породи за виробничими типами і генотипом

\begin{tabular}{ccccccc}
\hline \multirow{2}{*}{ Групи } & \multicolumn{2}{c}{ Кількість } & \multicolumn{3}{c}{ Виробничі типи } \\
\cline { 2 - 7 } & корів & \multicolumn{2}{c}{ молочний } & \multicolumn{2}{c}{ молочно-м'ясний } \\
\cline { 2 - 7 } & гол. & $\% 4$ & гол. & гол. & \% \\
\hline I & 226 & 70,4 & 10 & 9,4 & 64 & 20,0 \\
II & 320 & 100 & 178 & 56,2 & 78 & 24,4 \\
Разом & 320,6 & 142 & 44,4 \\
\hline
\end{tabular}

Серед корів із кровністю за голштинською породою до $75 \%$ до молочного типу віднесено 30 гол., або $9,4 \%$, молочно-м'ясного - 64 гол., або $20,0 \%$. Як і можна було очікувати, найбільша кількість корів молочного напрямку продуктивності спостерігається серед висококровних тварин із часткою спадковості голштинів понад $75 \%$ - 148 гол., або $46,2 \%$, а молочно-м'ясного типу практично удвічі менше - 78 гол., або $24,4 \%$. Отже, результати комплексної оцінки бу-
Визначення виробничих типів проводили згідно 3 рекомендаціями 3 оцінки типу тілоскладу молочної худоби Держагропрому України. У результаті проведеної оцінки було виділено дві групи тварин: молочного типу та молочно-м'ясного. Одночасно в кожному виробничому типі методом генеалогічного аналізу були встановлені дві групи корів: I - до 75\% і II понад 75\% частки спадковості голштинської породи. Піддослідні тварини знаходилися в однакових умовах годівлі, догляду та утримання.

Живу масу корів визначали шляхом контрольного зважування раз на рік. Екстер'єрні параметри у піддослідних тварин вивчали на основі взяття основних промірів статей тіла, визначення індексів будови тіла та окомірної оцінки. Товщину шкіри визначали за методикою, описаною Е.Я. Арзуманяном (Arzumanjan, 1957). Реберний кут, утворений між хребтом і останнім ребром, вимірювали спеціальним приладом, запропонованим У. Дюрстом.

\section{Результати та їх обговорення}

Проведеною оцінкою екстер'єрно-конституційних параметрів піддослідних тварин виявлено, що із 320 корів до молочного типу належали 178 гол., або $55,6 \%$, а до молочно-м'ясного типу - 142 гол., або $44,4 \%$ (табл. 1 ). 
Таблиця 2

Маса тіла корів різних виробничих типів, кг

\begin{tabular}{|c|c|c|c|c|c|c|}
\hline \multirow{3}{*}{ Виробничі типи } & \multicolumn{6}{|c|}{ Отелення } \\
\hline & \multicolumn{2}{|r|}{ перше } & \multicolumn{2}{|c|}{ друге } & \multicolumn{2}{|c|}{ третє і старше } \\
\hline & $\mathrm{n}$ & $\mathrm{M} \pm \mathrm{m}$ & $\mathrm{n}$ & $\mathrm{M} \pm \mathrm{m}$ & $\mathrm{n}$ & $\mathrm{M} \pm \mathrm{m}$ \\
\hline молочний & 55 & $485,1 \pm 3,0$ & 51 & $547,5 \pm 4,2$ & 72 & $585,7 \pm 3,2$ \\
\hline молочно-м'ясний & 45 & $492,7 \pm 4,0$ & 39 & $560,4 \pm 4,3 *$ & 58 & $597,2 \pm 3,6$ \\
\hline
\end{tabular}

Як свідчать дані таблиці 2, тварини молочном'ясного типу за масою тіла дещо переважають аналогів молочного напрямку продуктивності. Так, після першого отелення корови I групи порівняно із тваринами II групи мали меншу масу тіла на 7,6 кг (різниця невірогідна), після другого - на 12,9 кг $(\mathrm{P}<0,05)$ та після третього отелення і старші - на 11,5 кг (різниця невірогідна).

Після першого отелення не виявлено суттєвої різниці між масою тіла тварин молочного та молочном’ясного типів різної кровності (табл. 3).
Маса тіла була в межах 484,8-498,6 кг. Однак за цим показником первістки молочно-м'ясного типу дещо переважали своїх одногенотипових ровесниць молочного напрямку продуктивності - на 5,9-10,8 кг зі статистично невірогідною різницею. Аналогічна ситуація спостерігалася після другого отелення. Після третього і старших отелень жодна із генотипових груп тварин також не мала вірогідної переваги за масою тіла, яка знаходилася в межах 583,9-601,4 кг, хоч спостерігалася тенденція до іiі збільшення у висококровних за голштинами корів.

Таблиця 3

Маса тіла піддослідних корів, кг

\begin{tabular}{cccccccc}
\hline \multirow{2}{*}{ Виробничі типи } & \multicolumn{9}{c}{ Отелення } \\
\cline { 3 - 7 } & Групи & \multicolumn{2}{c}{ перше } & \multicolumn{2}{c}{ друге } & \multicolumn{2}{c}{ третє і старше } \\
\cline { 3 - 7 } & & $\mathrm{n}$ & $\mathrm{M} \pm \mathrm{m}$ & $\mathrm{n}$ & $\mathrm{M} \pm \mathrm{m}$ & $\mathrm{n}$ & $\mathrm{M} \pm \mathrm{m}$ \\
\hline \multirow{2}{*}{ Молочний } & $\mathrm{I}$ & 4 & $487,8 \pm 8,6$ & 6 & $553,7 \pm 10,5$ & 20 & $583,9 \pm 6,6$ \\
& $\mathrm{II}$ & 51 & $484,8 \pm 3,1$ & 45 & $546,7 \pm 4,4$ & 52 & $586,2 \pm 3,6$ \\
\multirow{2}{*}{ Молочно-м'ясний } & $\mathrm{I}$ & 13 & $498,6 \pm 8,4$ & 18 & $564,3 \pm 5,2$ & 33 & $593,8 \pm 5,9$ \\
& $\mathrm{II}$ & 32 & $490,2 \pm 4,0$ & 21 & $556,8 \pm 5,6$ & 25 & $601,4 \pm 5,9$ \\
\hline
\end{tabular}

Коефіцієнт мінливості маси тіла після першого отелення у тварин окремих підгруп становив 5,0 $6,4 \%$, після другого - 5,7-6,8\%, а після третього i подальших отелень $-6,2-7,2 \%$. Як видно із одержаних результатів, коефіцієнт мінливості маси тіла не перевищував 7,2\%, що свідчить про невисоку фенотипову мінливість даної ознаки. Це є однією із причин, що ускладнює селекцію маточного поголів'я на збільшення маси тіла.

Як відомо, одним із показників, які характеризують розмір будови тіла, є проміри тварин. Визначені висотні проміри і глибини грудей корів української чорно-рябої молочної породи в розрізі лактацій наведено в таблиці 4.

Із даних таблиці 4 видно, що проміри висоти в холці, в спині, в крижах і глибина грудей з віком зростали у тварин усіх генотипів. В усі лактації найбільшими промірами характеризувалися корови молочного типу з часткою крові голштинів понад 75\%. Так, порівняно з ровесницями інших підгруп вони мали більшу висоту в холці за першу лактацію на 0,6-1,9 см, за другу лактацію - на 0,6-1,5 см (різниця невірогідна) і за третю лактацію і старше - на 1,1-3,3 см (P < 0,001). Подібна ситуація спостерігалася між тваринами різних генотипів і щодо промірів висоти в спині і в крижах. При порівнянні промірів висоти тіла між висококровними коровами молочно-м'ясного типу з низькокровними молочного типу встановлено, що останні відзначалися меншими промірами висоти в холці, в спині та в крижах.

У таблиці 5 показано проміри довжини і обхвату тіла піддослідних корів у розрізі лактацій.

Дані таблиці показують, що за косою довжиною тулуба первістки окремих груп відрізняються незначно. Зокрема даний показник у низькокровних корів як молочного, так і молочно-м'ясного типів був майже однаковим (154,3-154,4 см). Зі зростанням частки крові голштинів спостерігається деяке збільшення косої довжини тулуба у тварин обох типів. Серед повновікових корів вірогідну перевагу мали тварини молочного типу II групи 165,3 см проти 160,7 cм (P $<0,001)$. Подібна картина спостерігається і при порівнянні тварин окремих підгруп за косою довжиною заду.

При порівнянні параметрів обхвату грудей встановлено, що більшими вони $є$ у висококровних первісток, причому корови молочно-м'ясного типу переважають за цими показниками аналогів молочного типу на 2,7 см $(\mathrm{P}<0,05)$ і на 1,6 см $(\mathrm{P}>0,05)$ відповідно. Що стосується обхвату грудей у повновікових корів, то варто виділити факт переваги за цим показником тварин із часткою кровності голштинів понад 75\%.

У таблиці 6 наведені широтні проміри піддослідних корів. 
Таблиця 4

Проміри висоти тулуба і глибини грудей піддослідних корів, см (M \pm m)

\begin{tabular}{|c|c|c|c|c|c|}
\hline \multirow{2}{*}{ Виробничі типи } & \multirow{2}{*}{ Групи } & \multicolumn{3}{|c|}{ Висота в } & \multirow{2}{*}{$\begin{array}{c}\text { Глибина } \\
\text { грудей }\end{array}$} \\
\hline & & холці & спині & крижах & \\
\hline \multicolumn{6}{|c|}{ I лактація } \\
\hline \multirow{2}{*}{ Молочний } & $I(n=4)$ & $129,1 \pm 1,64$ & $131,0 \pm 1,64$ & $134,5 \pm 1,50$ & $70,1 \pm 2,04$ \\
\hline & II $(\mathrm{n}=51)$ & $131,0 \pm 0,36$ & $132,5 \pm 0,36$ & $135,2 \pm 0,31$ & $72,2 \pm 0,46$ \\
\hline \multirow{2}{*}{ Молочно-м'ясний } & $\mathrm{I}(\mathrm{n}=13)$ & $129,3 \pm 0,90$ & $130,6 \pm 0,80$ & $133,9 \pm 0,80$ & $70,6 \pm 0,98$ \\
\hline & II $(\mathrm{n}=32)$ & $130,4 \pm 0,35$ & $133,1 \pm 0,40$ & $136,3 \pm 0,35$ & $71,9 \pm 0,57$ \\
\hline \multicolumn{6}{|c|}{ II лактація } \\
\hline \multirow{2}{*}{ Молочний } & $\mathrm{I}(\mathrm{n}=6)$ & $131,5 \pm 1,09$ & $133,8 \pm 1,09$ & $136,5 \pm 0,95$ & $71,5 \pm 2,18$ \\
\hline & II $(\mathrm{n}=45)$ & $133,0 \pm 0,30$ & $135,4 \pm 0,27$ & $137,9 \pm 0,24$ & $72,9 \pm 0,41$ \\
\hline \multirow{2}{*}{ Молочно-м'ясний } & $\mathrm{I}(\mathrm{n}=18)$ & $131,8 \pm 0,52$ & $133,1 \pm 0,52$ & $135,4 \pm 0,40$ & $71,6 \pm 0,63$ \\
\hline & II $(\mathrm{n}=21)$ & $132,4 \pm 0,44$ & $136,1 \pm 0,38$ & $138,2 \pm 0,38$ & $72,7 \pm 0,93$ \\
\hline \multicolumn{6}{|c|}{ III лактація і старше } \\
\hline \multirow{2}{*}{ Молочний } & $\mathrm{I}(\mathrm{n}=20)$ & $133,4 \pm 0,41$ & $135,8 \pm 0,37$ & $137,7 \pm 0,32$ & $73,6 \pm 0,64$ \\
\hline & II $(\mathrm{n}=52)$ & $136,2 \pm 0,33 \circ \circ \circ$ & $138,9 \pm 0,28$ & $140,2 \pm 0,25^{\circ \circ \circ}$ & $75,9 \pm 0,48 \circ \circ$ \\
\hline \multirow{2}{*}{ Молочно-м'ясний } & $\mathrm{I}(\mathrm{n}=33)$ & $132,9 \pm 0,43$ & $136,1 \pm 0,43$ & $138,6 \pm 0,39$ & $72,9 \pm 0,55$ \\
\hline & II $(n=25)$ & $135,1 \pm 0,58^{\circ \circ}$ & $138,8 \pm 0,58^{\circ \circ \circ}$ & $140,7 \pm 0,49 \circ \circ$ & $75,2 \pm 0,72^{\circ}$ \\
\hline
\end{tabular}

\section{Таблиця 5}

Проміри довжини і обхвату тіла у піддослідних корів, см (M \pm m)

\begin{tabular}{|c|c|c|c|c|c|}
\hline \multirow{2}{*}{ Виробничі типи } & \multirow{2}{*}{ Групи } & \multicolumn{2}{|c|}{ Коса довжина } & \multicolumn{2}{|c|}{ Обхват } \\
\hline & & тулуба & заду & грудей & п’ястка \\
\hline \multicolumn{6}{|c|}{ I лактація } \\
\hline \multirow{2}{*}{ Молочний } & $\mathrm{I}(\mathrm{n}=4)$ & $154,3 \pm 1,22$ & $51,4 \pm 0,82$ & $185,5 \pm 1,50$ & $17,9 \pm 0,27$ \\
\hline & II $(\mathrm{n}=51)$ & $154,9 \pm 0,59$ & $51,6 \pm 0,18$ & $186,6 \pm 0,64$ & $18,0 \pm 0,08$ \\
\hline \multirow{2}{*}{$\begin{array}{c}\text { Молочно- } \\
\text { м'ясний }\end{array}$} & $\mathrm{I}(\mathrm{n}=13)$ & $154,4 \pm 1,43$ & $51,5 \pm 0,45$ & $187,1 \pm 1,52$ & $18,1 \pm 0,27$ \\
\hline & II $(\mathrm{n}=32)$ & $155,6 \pm 0,84$ & $51,9 \pm 0,31$ & $189,3 \pm 0,93 *$ & $18,7 \pm 0,09 * * *^{\circ}$ \\
\hline \multicolumn{6}{|c|}{ II лактація } \\
\hline \multirow{2}{*}{ Молочний } & $I(n=6)$ & $157,2 \pm 1,63$ & $52,9 \pm 1,09$ & $192,7 \pm 2,18$ & $19,0 \pm 0,54$ \\
\hline & II $(n=45)$ & $159,7 \pm 0,71$ & $53,2 \pm 0,22$ & $191,5 \pm 0,57$ & $18,8 \pm 0,11$ \\
\hline \multirow{2}{*}{$\begin{array}{c}\text { Молочно- } \\
\text { м'ясний }\end{array}$} & $\mathrm{I}(\mathrm{n}=18)$ & $159,3 \pm 1,61$ & $53,1 \pm 0,46$ & $192,5 \pm 1,09$ & $19,2 \pm 0,17$ \\
\hline & II $(\mathrm{n}=21)$ & $159,9 \pm 1,20$ & $53,3 \pm 0,49$ & $193,9 \pm 1,31$ & $19,0 \pm 0,16$ \\
\hline \multicolumn{6}{|c|}{ III лактація і старше } \\
\hline \multirow{2}{*}{ Молочний } & $\mathrm{I}(\mathrm{n}=20)$ & $160,7 \pm 0,91$ & $53,6 \pm 0,41$ & $193,3 \pm 1,23$ & $19,9 \pm 0,18$ \\
\hline & II $(\mathrm{n}=52)$ & $165,3 \pm 0,73^{\circ \circ \circ}$ & $55,1 \pm 0,28^{\circ \circ}$ & $195,8 \pm 1,03$ & $19,7 \pm 0,13$ \\
\hline \multirow{2}{*}{$\begin{array}{c}\text { Молочно- } \\
\text { м'ясний }\end{array}$} & $\mathrm{I}(\mathrm{n}=33)$ & $162,4 \pm 0,82$ & $54,4 \pm 0,31$ & $194,9 \pm 1,09$ & $20,3 \pm 0,16$ \\
\hline & II $(\mathrm{n}=25)$ & $163,6 \pm 1,12$ & $54,5 \pm 0,40$ & $196,4 \pm 0,71$ & $20,5 \pm 0,22 * *$ \\
\hline
\end{tabular}

Таблиця 6

Широтні проміри піддослідних корів, см (M \pm m)

\begin{tabular}{|c|c|c|c|c|c|}
\hline \multirow[b]{2}{*}{ Виробничі типи } & \multirow[b]{2}{*}{ Групи } & \multicolumn{4}{|c|}{ Ширина } \\
\hline & & грудей & в клубах & $\begin{array}{c}\text { в тазо-стегнових } \\
\text { з'єднаннях }\end{array}$ & $\begin{array}{c}\text { в сідничних } \\
\text { горбах } \\
\end{array}$ \\
\hline \multicolumn{6}{|c|}{ I лактація } \\
\hline \multirow{2}{*}{ Молочний } & $I(n=4)$ & $39,0 \pm 0,82$ & $48,8 \pm 1,09$ & $43,1 \pm 0,95$ & $32,6 \pm 1,09$ \\
\hline & $\mathrm{II}(\mathrm{n}=51)$ & $38,6 \pm 0,33$ & $49,9 \pm 0,26$ & $43,6 \pm 0,28 *$ & $33,1 \pm 0,28 * *$ \\
\hline \multirow{2}{*}{$\begin{array}{c}\text { Молочно- } \\
\text { м’ясний }\end{array}$} & $\mathrm{I}(\mathrm{n}=13)$ & $39,9 \pm 0,80$ & $48,6 \pm 0,71$ & $42,0 \pm 0,62$ & $30,9 \pm 0,80$ \\
\hline & II $(\mathrm{n}=32)$ & $40,8 \pm 0,40 * * *$ & $49,4 \pm 0,44$ & $42,2 \pm 0,53$ & $31,4 \pm 0,44$ \\
\hline \multicolumn{6}{|c|}{ II лактація } \\
\hline \multirow{2}{*}{ Молочний } & $I(n=6)$ & $42,0 \pm 1,50$ & $51,5 \pm 1,50$ & $45,4 \pm 1,22$ & $34,1 \pm 1,09$ \\
\hline & II $(n=45)$ & $41,0 \pm 0,33$ & $51,7 \pm 0,35$ & $46,1 \pm 0,30$ & $35,6 \pm 0,27$ \\
\hline \multirow{2}{*}{$\begin{array}{c}\text { Молочно- } \\
\text { м’ясний }\end{array}$} & $\mathrm{I}(\mathrm{n}=18)$ & $43,2 \pm 0,63$ & $50,4 \pm 0,69$ & $44,6 \pm 0,57$ & $33,6 \pm 0,63$ \\
\hline & $\mathrm{II}(\mathrm{n}=21)$ & $42,9 \pm 0,55 * *$ & $51,0 \pm 0,60$ & $45,8 \pm 0,49$ & $34,9 \pm 0,65$ \\
\hline \multicolumn{6}{|c|}{ III лактація і старше } \\
\hline \multirow{2}{*}{ Молочний } & $\mathrm{I}(\mathrm{n}=20)$ & $44,6 \pm 0,64$ & $54,0 \pm 0,55$ & $48,3 \pm 0,55 *$ & $36,9 \pm 0,59$ \\
\hline & II $(\mathrm{n}=52)$ & $43,4 \pm 0,38$ & $55,1 \pm 0,35$ & $49,4 \pm 0,38$ & $37,2 \pm 0,33$ \\
\hline \multirow{2}{*}{$\begin{array}{l}\text { Молочно- } \\
\text { м’ясний }\end{array}$} & $\mathrm{I}(\mathrm{n}=33)$ & $45,9 \pm 0,47$ & $52,9 \pm 0,39$ & $46,8 \pm 0,35$ & $35,9 \pm 0,39$ \\
\hline & II $(n=25)$ & $45,1 \pm 0,58 *$ & $54,5 \pm 0,49^{\circ}$ & $48,3 \pm 0,49^{\circ}$ & $36,7 \pm 0,45$ \\
\hline
\end{tabular}


Одержані дані свідчать, що тварини молочном'ясного типу різної кровності мали ширші груди, ніж тварини молочного типу. Найбільшою шириною грудей відзначалися висококровні за голштинами корови молочно-м'ясного типу, які переважали ровесниць молочного типу тієї ж кровності за першу лактацію на 2,2 см $(\mathrm{P}<0,001)$, за другу лактацію - на 1,9 см $(\mathrm{P}<0,01)$ і за третю лактацію і подальші - на 1,7 см $(\mathrm{P}<0,05)$. Проте висококровні тварини молочного типу помітно виділяються більшими широтними розмірами задньої третини тулуба, зокрема, за шириною в клубах, в тазо-стегнових з'єднаннях, в сідничних горбах. Вказані проміри в розрізі лактацій у висококровних корів порівняно 3 тваринами з часткою спадковості голштинів до 75\% переважно вищі в обох виробничих типах. Це свідчить, що з наростанням в генотипах частки спадковості голштинів і серед тварин молочно-м'ясного типу формуються екстер'єрні ознаки, характерні для молочного типу.

При проведенні оцінки будови тіла корів різних виробничих типів та кровностей нами було визначено товщину шкіри та реберний кут за У. Дюрстом (табл. 7).

\section{Таблиця 7}

Товщина шкіри та реберний кут у корів різної кровності та виробничих типів, $(\mathrm{n}=25, \mathrm{M} \pm \mathrm{m})$

\begin{tabular}{|c|c|c|c|c|}
\hline \multirow{2}{*}{ Виробничі типи } & \multirow{2}{*}{ Групи } & \multicolumn{2}{|c|}{ Товщина шкіри, мм } & \multirow{2}{*}{ Реберний кут, } \\
\hline & & на лікті & на останньому ребрі & \\
\hline \multirow{2}{*}{ Молочний } & $\mathrm{I}$ & $2,77 \pm 0,08$ & $4,37 \pm 0,07$ & $127,8 \pm 1,2$ \\
\hline & II & $2,68 \pm 0,07$ & $4,41 \pm 0,06$ & $132,8 \pm 1,2^{\circ \circ}$ \\
\hline \multirow{2}{*}{ Молочно-мясний } & I & $3,14 \pm 0,08 * * *$ & $4,90 \pm 0,08 * * *$ & $124,5 \pm 0,9 *$ \\
\hline & II & $3,01 \pm 1,00$ & $4,76 \pm 0,09 * *$ & $129,2 \pm 1,3^{* 000}$ \\
\hline
\end{tabular}

Як свідчать дані таблиці, тварини молочном'ясного типу за товщиною шкіри переважають аналогів молочного напрямку продуктивності. Так, найвищим іiі показником характеризуються корови молочно-м'ясного типу I групи - 3,14 мм - на лікті та 4,90 мм - на останньому ребрі. Вони вірогідно переважають тварин тієї ж кровності молочного типу на 0,37 мм $(\mathrm{P}<0,001)$ та на 0,53 мм $(\mathrm{P}<0,001)$ відповідно. Подібна картина спостерігається і серед корів із часткою спадковості голштинів понад 75\%. При ви- значенні реберного кута встановлено, що найбільший він у висококровних тварин молочного типу $\left(132,8^{\circ}\right)$. Вони за цим показником вірогідно переважають аналогів II групи на $3,6^{\circ}(\mathrm{P}<0,05)$.

Відомо, що індекси будови тіла дають певну уяву про розвиток одних статей тіла відносно інших. Відносні величини будови тіла піддослідних повновікових корів різних напрямків продуктивності й генотипів наведено в таблиці 8.

Таблиця 8

Індекси будови тіла піддослідних повновікових корів, \%

\begin{tabular}{lcccc}
\hline & \multicolumn{4}{c}{ Виробничі типи, групи } \\
\cline { 2 - 5 } \multicolumn{1}{c}{ Індекси } & \multicolumn{2}{c}{ молочний } & молочно-м'ясний \\
\cline { 2 - 5 } & $\mathrm{I}$ & $\mathrm{II}$ & $\mathrm{I}$ & $\mathrm{II}$ \\
\cline { 2 - 5 } & $\mathrm{n}=20)$ & $\mathrm{n}=52)$ & $\mathrm{n}=33)$ & 44,3 \\
\hline Довгоногості & 44,8 & 44,3 & 45,1 & 102,7 \\
Перерослості & 102,5 & 102,2 & 102,8 & 60,0 \\
Грудний & 60,6 & 57,2 & 62,9 & 82,8 \\
Тазо-грудний & 82,6 & 78,8 & 86,8 & 121,1 \\
Розтягнутості & 120,5 & 121,4 & 122,2 & 19,7 \\
Збитості & 120,3 & 118,8 & 120,0 \\
Шилозадості & 146,3 & 148,1 & 147,4 & 15,2 \\
Костистості & 14,9 & 14,5 & 15,3 & 121,5 \\
Масометричний & 119,8 & 117,9 & 121,1 & \\
(за Д. Вінничуком) & & & & \\
\hline
\end{tabular}

Аналіз свідчить, що за індексами довгоногості, грудним, тазо-грудним, розтягнутості та костистості низькокровні тварини молочно-м'ясного типу незначно переважають ровесниць інших підгруп. За індексом перерослості вірогідної різниці між окремими групами корів не виявлено, але простежується тенденція до його збільшення у тварин молочно-м'ясного типу. За індексом збитості, істотної різниці між окремими підгрупами тварин не виявлено. За показником індексу шилозадості корови молочного типу незначно поступаються тваринам молочно-м'ясного напрямку продуктивності.

Узагальнюючим показником, який характеризує екстер'єрний тип тварини, є масометричний коефіцієнт. Він досить точно відображає відношення маси тіла (кг) до його поверхні (см). Аналіз таблиці показує, що найбільшим він був у корів молочно-м'ясного типу обох груп: 121,1-121,5\% проти 117,9-119,8\% у тварин інших груп. Одержані дані свідчать, що корови молочного напрямку продуктивності були більш 
високорослі, розтягнуті, а на одиницю поверхні тіла у них припадала менша частка маси тіла, що характерно для тварин молочного напрямку продуктивності.

Коефіцієнт кореляції між масою тіла та масометричним коефіцієнтом у тварин усіх підгруп за першу, другу та третю лактації і подальші позитивний і перебуває у межах 0,83-0,98.

\section{Висновки}

Таким чином, за екстер'єрно-конституційними параметрами корови української чорно-рябої молочної породи відповідають типу тварин молочного напряму продуктивності, причому зі збільшенням кровності за голштинською породою ознаки молочності виражені краще. Одержані нами результати узгоджуються із висновками інших вчених, які наголошують на збільшенні маси тіла та промірів тіла у висококровних тварин. При цьому вказані особливості стають найбільш помітнішими за умов підвищеної годівлі (Koval, 2003; Khmelnychyi, 2003; Pelekhatyi and Omelkovych, 2008; Cherniak and Honcharuk, 2011).

\section{References}

Ajsanov, Z. (1998). Opredelenie proizvodstvennyh tipov krupnogo rogatogo skota molochnyh porod. Molochnoe i mjasnoe skotovodstvo, 1, 29-30 (in Russian).

Arzumanjan, E.A. (1957). Osnovy inter'era krupnogo rogatogo skota. M.: Gos. izd. s.-h. lit. (in Russian).

Bodnaruk, V.Y., Muzyka, L.I., Bodnar, P.V., Zhmur, A.J., \& Orihivsjkyj, T.V. (2017). New possibilities of effective breeding in cattle based on the study of the genome. Scientific Messenger LNUVMB, 19(79), 32 37. doi: 10.15421/nvlvet7907.

Burkat, V.P., Polupan, Yu.P., \& Yovenko, I.V. (2004). Liniina otsinka koriv za typom. K.: Ahrarna nauka (in Ukrainian).

Cherniak, N., \& Honcharuk, O. (2011). Eksterier koriv ukrainskoi chorno-riaboi molochnoi porody riznykh linii. Tvarynnytstvo Ukrainy, 1-2, 22-25 (in Ukrainian).

Dundun, V.L. (2016). Development of suckling cattle breeding of Lvov. Scientific Messenger LNUVMBT named after S.Z. Gzhytskyj, 18, 2(69), 48-52. doi: 10.15421/nvlvet6908.

Fedak, V.D. (2001). Metodyka kompleksnoi otsinky typu konstytutsii velykoi rohatoi khudoby. Visnyk Sumskoho NAU, 178-180 (in Ukrainian).

Khmelnychyi, L.M. (2003). Eksteriernyi typ ta produktyvnist koriv ukrainskoi chorno-riaboi molochnoi porody. Naukovo-tekhnichnyi biuleten Instytutu tvarynnytstva UAAN, 84, 142-146 (in Ukrainian).

Koval, T.P. (2003). Formuvannia eksterieru koriv chervonoi molochnoi khudoby ta yoho zviazok z produktyvnistiu. Visnyk ahrarnoi nauky, 9, 70-72 (in Ukrainian).

Kuziv, M.I., \& Fedorovych, E.I. (2016). Reppoductive ability of ukrainian black and white dairy cows. Scientific Messenger LNUVMBT named after S.Z. Gzhytskyj, 18, 2(67), 120-123. doi: $10.15421 /$ nvlvet6727.

Pelekhatyi, M.S., \& Omelkovych, S.P. (2008). Eksterierno-konstytutsionalni osoblyvosti koriv ukrainskoi chor-no-riaboi molochnoi porody riznykh vyrobnychykh typiv. Naukovyi visnyk LNUVMBT imeni S.Z. Gzhytskoho, 10, 3(38), 106-113 (in Ukrainian).

Poslavska, Yu., Fedorovych, E., \& Bodnar, P. (2016). Features of growth of the living mass of different ukrainian black-spotted lines dairy cows breed during the period of their breeding. Scientific Messenger LNUVMBT named after S.Z. Gzhytskyj, 18, 2(67), 199-203. doi: 10.15421/nvlvet6744.

Ruban, M.S. (2003). Obgruntuvannia parametriv eksteriernoi otsinky molochnoi khudoby. Visnyk ahrarnoi nauky, 8, 71-73 (in Ukrainian).

Shcherbatyi, Z.Ie., Bodnar, P.V., \& Kropyvka, Yu.H. (2016). Dynamika rostu zhyvoi asy ta eksteriernokonstytutsiini osoblyvosti koriv ukrainskoi chornoriaboi molochnoi porody riznykh typiv konstytutsii. Naukovyi visnyk LNUVMBT im. S.Z. Hzhytskoho, 18, 2(67), 281-286. doi: 10.15421/nvlvet6761 (in Ukrainian).

Shcherbatyj, Z.Y., Bodnar, P.V., \& Kropyvka, Y.G. (2017). Milk productivity and reproductive ability of ukrainian black-spotted dairy breed cows of different type of constitution. Scientific Messenger LNUVMBT named after S.Z. Gzhytskyj, 19(74), 182-187. doi: 10.15421/nvlvet7440.

Siratskyi, Y., Merkushyn, V., \& Fedorovych, Ye. (2001). Konstytutsiia velykoi rohatoi khudoby yak mira harmonii bu-dovy tila. Propozytsiia, 12, 82-84 (in Ukrainian).

Vinnychuk, D.T. (1973). Vydilennia typiv tvaryn u molochnomu skotarstvi. Molochno-miasne skotarstvo, 32, 31-32 (in Ukrainian).

Yefimenko, M.Ia., Podoba, B.Ie., \& Antonenko, V.I. (2000). Metodychni rekomendatsii po vyznachenniu bazhanoho typu pleminnykh tvaryn v skotarstvi. Kyiv.: Vydavnychyi tsentr NAU (in Ukrainian). 